\title{
Iznik Ceramics: History and Present-Day
}

\author{
By Ezgi Gökçe*
}

Iznik is an important production centre in the history of ceramic art. In the $15^{\text {th }}-16^{\text {th }}$ century, following the establishment of the Ottoman Empire, the name of Iznik became famous throughout the world due to the development of a ceramics production. Iznik ceramics represent an amazing technical innovation in the history of Turkish ceramic art. Combining the Ottoman style with external influences from China, Asia, the Balkans and even Europe, Iznik vessels and tiles reached their peak within the Ottoman ceramic art. The court's patronage stimulated and supported the development of an artistically and technically advanced ceramic industry in Iznik. In this study, the specific production and decoration pecularities of Iznik ceramics that are found in some of the written documents are introduced. Accordingly, it is intended to put forward the change and the transformations which are seen in present-day production and decoration techniques.

\section{History of Iznik Ceramics and Their Characteristics}

Ceramic production in Iznik dates back to the $4^{\text {th }}$ century BC. It is thought that traditions of ceramic production in Mesopotamia, Egypt and Asia have effected ceramic production in Iznik. But Iznik gained the opportunity of proving itself especially after mid - $15^{\text {th }}$ century as a result of technological improvements. ${ }^{1}$ The ceramics (Glazed Tiles) of Iznik ${ }^{2}$ which were produced in the Ottoman Era and which nowadays are generally classified in two groups, those produced out of red coloured mud and those produced out of white fritted mud. Especially for daily use; it is seen that slip applications and also colourful glazes were used in ceramics of the period between the $14^{\text {th }}$ and $15^{\text {th }}$ centuries which were produced out of red mud. Such techniques indicate the connection

\footnotetext{
*Assistant Professor, Department of Traditional Turkish Arts, Faculty of Fine Arts, Usak University, Turkey.

1. Sitare Turan Bakır, "Osmanlı Sanatında Bir Zirve Iznik Çini ve Seramikleri" (Copper, a Summit in Ottoman Art Iznik Tiles and Ceramics), in Anadolu'da Türk Devri Çini ve Seramik Sanatı (Turkish Revolutionary Tile and Ceramic Art in Anatolia), ed. Gönül Öney, \& Zehra Çobanlı (İstanbul: T.C. Kültür ve Turizm Bakanlığı Yayınları, 2007), 280.

2. For more information about the ceramics of Iznik: Nurhan Atasoy, \& Julian Raby, Iznik Seramikleri (Iznik Ceramics) (London: Alexandria Press, 1989); Hülya Bilgi, Ateşin Oyunu: Sadberk Hanım Müzesi ve Ömer Koç Kolleksiyonlarmdan Iznik Çini ve Seramikleri (Fire Game: Iznik Tiles and Ceramics from Sadberk Hanım Museum and Ömer Koç Collections) (İstanbul: Vehbi Koç Vakfı Sadberk Hanım Müzesi Yayınları, 2009); John Carswell, Iznik Pottery (London: British Museum Press, 1998); Arthur Lane, Later Islamic Pottery: Persia, Syria, Egypt, Turkey (London: Faber \& Faber, 1957); Gönül Öney, \& Zehra Çobanl1, Anadolu'da Türk Devri Çini ve Seramik Sanatı (Turkish Revolutionary Tile and Ceramic Art in Anatolia) (İstanbul: T.C. Kültür ve Turizm Bakanlığı Yayınları, 2007); Oliver Watson, Ceramics from Islamic Lands (New York: Thames \& Hudson, 2005).
} 
between the Art of ceramics in the Ottoman Era and Seljukian Era. ${ }^{3}$ On the other side, what makes the ceramics that are produced out of white fritted mud so attractive and so beautiful are their bodies and decorations. The body of such ceramics constitute Granulated Quartz, Frit and white clay which improves the plasticity at a small amount.

Apart from their products, it cannot be told that there are many available written sources of information left from the Masters in Iznik. There is a Section concerning ceramics within the Leaflet $(700 / 1301)^{4}$ which scopes on valuable stones and which was written by Ebu'l Kasım who was a member of one of the families who dealt with ceramics in Keşan. This Section is a significant source written about the production of fritted ceramics. ${ }^{5}$ Moreover, the researches which are enabled by the constantly-improving technology also provide benefits in this aspect. The body used while producing ceramics of Iznik, together with the colouring agents and the glazes, the colours and the patterns constitute the real focus for attractiveness. Deep cases, big cases with standing legs, flat plates with wide edges, plates with shredded edges, pitchers, vases, jars and oillamps are significant elements of the ceramics of Iznik. Atasoy and Raby ${ }^{6}$ have used terms such as "Baba Nakkaş," "Düğüm Ustası," "Helezoni Tuğrakeş Üslûbu" for the pattern types observed on ceramics of Iznik since the era of Fatih Sultan Mehmet. Furthermore, the general methods that are observed in these ceramics can be examined under four general categories which correspond to four stages; and these four stages are stated to be corresponding to four periods of reign which follow each other. These stages are: the last decade of the reign of Fatih Sultan Mehmet (1451-1481), the reign of Sultan Bayezid the $2^{\text {nd }}(1481-1512)$, the reign of Sultan Selim the $1^{\text {st }}(1512-1520)$ and the first decade of the reign of Kanuni Sultan Süleyman (Suleiman the Magnificent) (15201566). The ceramics which were produced during the era of Fatih Sultan Mehmet are believed to be effected by the blue-white ceramics of Chinese and metal works. ${ }^{7}$ Beside the patterns, it is the size and the colours used within the ceramics which support this theory. The patterns designed by muralists within the centre of muralists in Topkap 1 were applied on the ceramics by the Masters of Iznik. In the beginning, curvy branches under dominancy of blue as a colour, patterns of rumi, lotus and palmet were used.

At the beginning, curved branches, Rumi, palmette and lotus motifs, which possessed blue-white colours, were used. An extensive workmanship

3. Bilgi, Ateşin Oyunu: Sadberk Hanım, 23.

4. James W. Allan, Abu'l-Qasim's Treatise on Ceramics (Iran, 1973), 11.

5. Atasoy, \& Raby, Iznik Seramikleri, 49.

6. Ibid.

7. For more information: Atasoy, \& Raby, Iznik Seramikleri; Géza Fehervari, Ceramics of the Islamic Lands (London: I. B. Tauris, 2000); Tim Stanley, "Iznik Ceramics Between Asia and Europe, 1470s-1550s," Arts of Asia 41, no. 6 (2011). 
draws the attention in the works of this period..$^{8}$ In the midst of the $16^{\text {th }}$ century, turquoise, then purple and green colours were seen in addition to the bluewhite colour that is seen on the underglazed decoration of the ceramics of Iznik. In this period qualified ceramics were produced. The white ground is very clean and solid, the glazes are colourless and transparent, and the colours of the paintings are vivid and shiny. With the contribution of the Ottoman palace atelier's effect and the patterns of wall ceramics that are ordered, the changes in the ceramics of Iznik have been observed since the midst of the $16^{\text {th }}$ century. By adding fluffy (coral) red, flowers such as roses, carnations, hyacinths, tulips and hatai and badges inform a new decoration style in which the naturalist tendency dominates. ${ }^{9}$ Rumi, Hatayi, cloud elements and animal figures appear on the ceramics of this period. In the art of Ottoman, the production of Turkish ceramics reached the highest quality level especially in the second period of the $16^{\text {th }}$ century. The new production gives a few clues, for its designs are directly relatable in a stylistic sense to court taste and court ideas and clearly reflect an appeal to court patronage. ${ }^{10}$ In the period from the $14^{\text {th }}$ century to the $20^{\text {th }}$ century, the ceramists of the Ottoman period revealed styles of the period with the excitement of renovating and producing to which the Empire adds acceleration power in every period, however infrastructure, decoration techniques, patterns and colours used are.

The institution known as the "Nakkashane" was founded in the court in İstanbul in the late $15^{\text {th }}$ century, and reached its zenith in the $16^{\text {th }}$ century. ${ }^{11}$

Ottoman painters frequently used paper cartoons, often pronounced, as the bases for their preparatory work. This practice was immediately adapted by the Iznik tile and ware makers for their own use. ${ }^{12}$ Artists from the Nakkashane would draw a design with black ink on paper, then artisans in the ceramic studios would pierce holes in the design and spread powder over the stencil, creating a dotted outline of the pattern once the stencil was lifted away (Figures 1-2). The use of stencils was crucial for creating both identically patterned tiles and modular designs. ${ }^{13}$ Paper cartoons allowed court artists to design great compositions in Istanbul that could be executed in brilliant colored glazes in

8. Atasoy, \& Raby, Iznik Seramikleri, 79.

9. Belgin Demirsar Arlı, \& Ara Altun, Anadolu Toprağının Hazinesi Çini Osmanlı Dönemi (Treasury of Anatolian Soil Tile Ottoman Period) (İstanbul: Kale Grubu Kültür Yayınları, 2008), 25.

10. Walter B. Denny, "Painting on Ceramic," Studio Potter 31, no. 1 (December 2002): 36. Art Source, EBSCOhost [Accessed: April 26, 2016].

11. Denny, Iznik: The Artistry of Ottoman Ceramics (London: Thames \& Hudson Press, 2005).

12. Denny, "Painting on Ceramic."

13. Denny, "Turkish Ceramics and Turkish Painting: The Role of the Paper Cartoon in Turkish Ceramic Production," in Essays in Islamic Art and Architecture in Honor of KatharinaOtto-Dorn, ed. Abbas Daneshvari (Malibu: Undena Publications, 1981), 30. 
Iznik. While the court artists were perfecting the means by which painting and ceramic decoration could be practiced with the same styles side by side, the Iznik artisans kept expanding the range of colors, developing a pale manganese-purple and a light green by the 1530s. Production at Iznik during this period was generally of a very high quality. ${ }^{14} \mathrm{~A}$ series of imperial firmans from the latter half of the 16th century refer to "examples" sent to Iznik from the capital. ${ }^{15}$

Figure 1. Detail of a Pierced Paper Stencil 18 $8^{\text {th }}$ Century

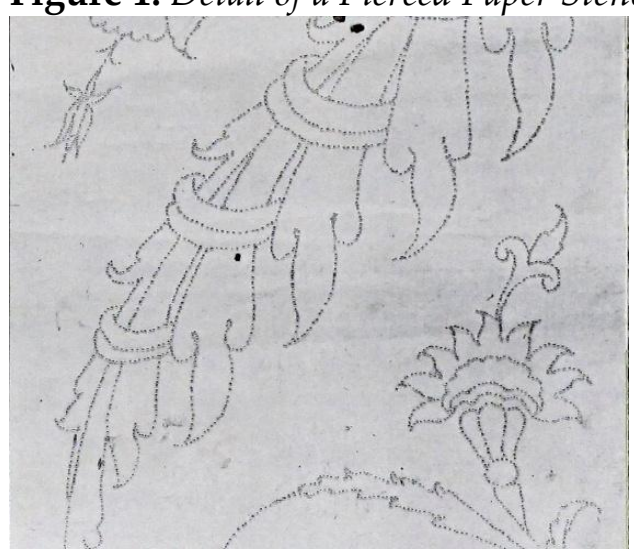

Source: Atasoy, \& Raby (1989), 56.

Figure 2. Pierced Paper Stencil (Garo Kürkman Collection)

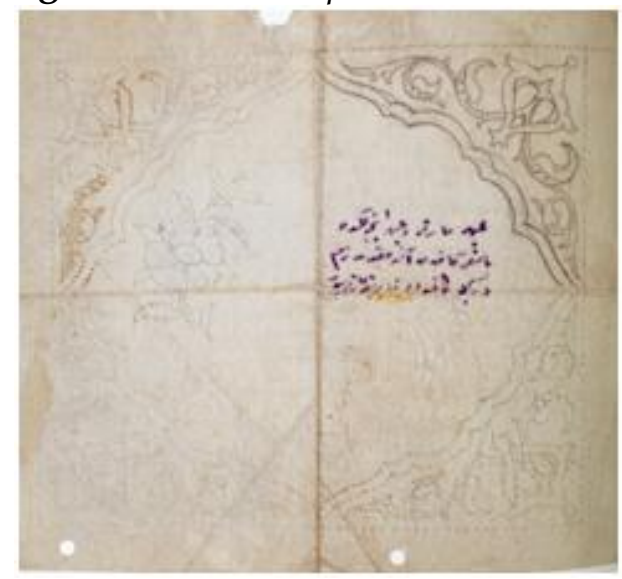

Source: Kürkman, $263 .{ }^{16}$

14. Denny, "Painting on Ceramic," 36.

15. For more information about the Imperial firmans for Iznik Tiles: Atasoy, \& Raby, Iznik Seramikleri; Denny, Iznik: The Artistry of Ottoman Ceramics; Ahmet Refik, "Iznik Çinileri - Hazinei Evrak Vesikalarına Nazaran" (Iznik Chinese - compared to Treasury Documents), Darülfünun Edebiyat Fakültesi Mecmuası 8, no. 4 (1932); Gürlu Necipoğlu, "From International Timurid to Ottoman: A Change in Taste in Sixteenth Century Ceramic Tiles," Muqarnas 7 (1990).

16. Garo Kürkman, Magic of Clay And Fire: A History of Kutahya Pottery and Potters (Istanbul: Suna and Inan Kırac, Foundation, 2006). 


\section{Characteristics of Traditional Production of Ceramics of Iznik in Present Day}

The ceramics of Iznik are produced for decorative purposes nowadays while there were produced for usage in Ottoman period. In the direction of advancing technology and researches, many trials were made and are being made about the ceramics of the Ottoman period. As a result of the studies, close results are obtained. In the studios and factories in the manufacturing process, low grade earthenware, stoneware and fritware (stonepaste) that are prepared in Kütahya are used. The underglaze paintings used in decors are manufactured from prepared pigments generally. Nowadays, many artisans use brush decoration with sirāt as a traditional method, also screen printing is made in the places that makes production with commercial concerns. Today the patterns and decoration methods are especially based on the old, classical artistic styles with classic compositions and classic motifs. On the other side some ceramics which are made by a classic technique, recreated with classic motifs.

In the studios, the patterns are prepared in accordance with the classical composition generally and new compositions are produced. While some studios use the same compositions and patterns, some of them use very different patterns and motifs.

\section{The Features of the Composition Seen on Ceramics of Iznik and Underglaze Decorations Technique}

The ceramics of Iznik are divided in specific categories in the compositions specified according to its styles. These sections are divided as style, composition and as a whole; they are divided in the elements that we identified as edge, cheek, and border (Figure 3). In the compositions that shall be applied to the surfaces of styles, the motifs that are not used alone generally are connected with each other in a different location and direction. The different patterns and motifs are applied to the surfaces like body, neck, cheek, bottom in specific styles and measures at the given concentration.

It is essential to establish coherence between the composition and the motifs to be applied to the surface with shape, size, colour and balance, correctly.

The palace atelier that reminds the educational institution in the Ottoman period composed the pattern program of the products manufactures in Iznik. It is seen that the design principles are known and applied in these compositions.

When the examinations that are done on the samples of Iznik ceramic plate decorations are considered; big-small relations in accordance with visual hierarchy, direction differences, the coherence between the middle pattern and edge pattern, the usage of light and dark shades of the colours, ground-motif relation, adding motion and vitality with the illusions that are done to eliminate the monotony in the repeating units, the usage of contrasts by forming a 
harmonious balance, providing the continuity of the motion by using colours that support rhythm and balance and by spreading the emphasis around the show that the designs of these patterns are done depending on specific rules.

Figure 3. Plate Parts, Border-Edge, Cheek, Bottom-Center

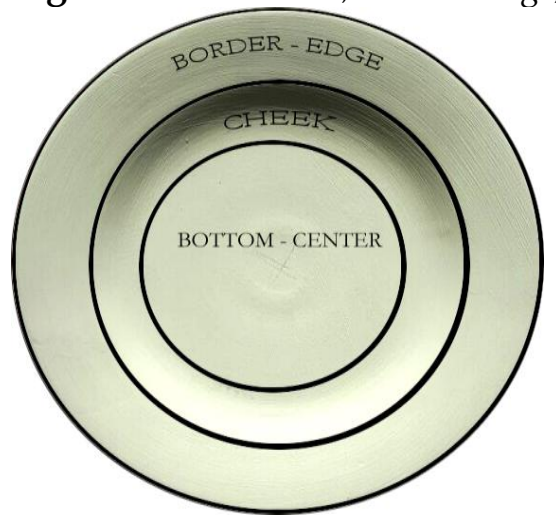

Source: Personal Archive.

In this study, the compositions used in the ceramics of Iznik and the decoration technique are explained. Although nevertheless the underglazed decoration technique is seen in all places that manufacture ceramic or in the places that the introduction is given about it, the methods and materials used in ceramic decoration are mentioned in this study.

The designs in ceramics of Iznik are made according to the style and surface to be decorated. The motifs ${ }^{17}$ that shall be used in this design are determined and the supportive motifs take place by the main motifs used in the composition. The part that draws attention on the surface consists of the main motifs and the remaining gaps are filled with the supportive motifs. In the composition, all of the motifs are placed in a particular discipline and in accordance with each other.

While preparing the composition for plate forms, the most important factor is the determination of the composition style. The composition types that are used while the main pattern is drawn in the plate forms can be listed as follows:

17. For more information about the Turkish Motifs: İnci A. Birol, \& Derman Çiçek, Türk Tezyini Sanatlarında Motifler (Motifs in Turkish Tezyin Sanatlar) (İstanbul: Kubbealtı Publications, 1995); Azade Akar, \& Cahide Keskiner, Türk Süsleme Sanatlarmda Desen ve Motif (Pattern and Motif in Turkish Decorative Arts) (İstanbul: Sanat ve Kültür Yayınları, 1978); Cahide Keskiner, Türk Süsleme Sanatlarında Stilize Çiçekler (Stylize Flowers in Turkish Decorating Arts) (Ankara: Kültür Bakanlığı Yayınları, 2000); ilhan Özkeçeci, Türk Sanatı'nda Kompozisyon (Composition in Turkish Art) (İstanbul: Yazıgen Publishing House, 2014); Faruk Şahin, Türk Çini Sanatı Süslemeciliği (Turkish Tile Art Ornamentation) (Anadolu: Anadolu University Publications, 1989). 
- Symmetrical Compositions

In this type of compositions; the pattern is designed on one side of a vertical line dividing the pattern in the exact middle, called the middle axis (Figures 4-5). Then the paper is folded over the middle axis and the designed composition is copied on the opposite side to obtain a symmetrical pattern. Thus, composition integrity is ensured. However, in this style of compositions generally the symmetry is broken by making some changes, especially in size, in some motifs at the bottom part of the plate or some other parts.

Figure 4. Iznik Plate $16^{\text {th }}$ Century

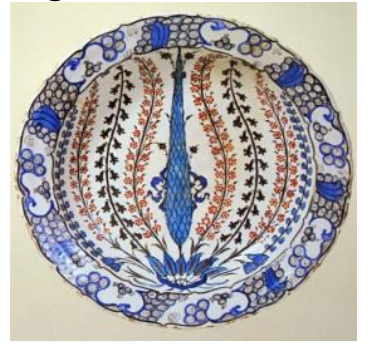

Source: Atasoy, \& Raby (1989), 299.

Figure 5. Iznik Plate $16^{\text {th }}$ Century

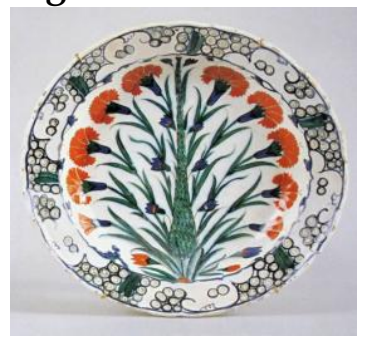

Source: Atasoy, \& Raby (1989), 309.

- Asymmetrical and Free Compositions

In this type of compositions, the motifs are placed in the entire dimension of the plate. Asymmetrical compositions constitute a very difficult composition type (Figures 6-7). It is widely used in motif arrangements featuring plants. The most beautiful samples of this composition type are seen in the $16^{\text {th }}$ century classical patterns.

Figure 6. Iznik Plate $16^{\text {th }}$ Century

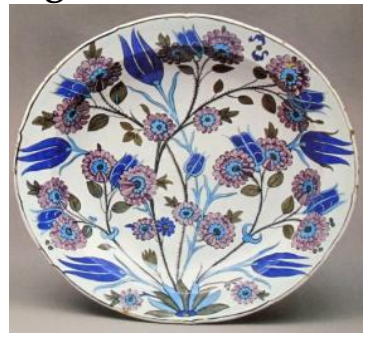

Source: Atasoy, \& Raby (1989), 209. 
Figure 7. Iznik Plate $16^{\text {th }}$ Century

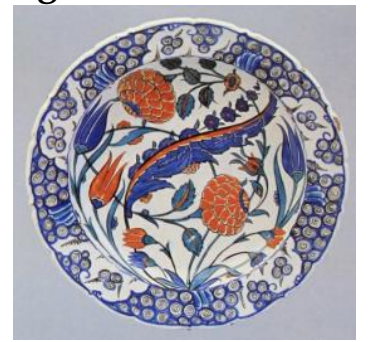

Source: Atasoy, \& Raby (1989), 333.

- Unicentric Compositions

This type of composition is also called centrally developed composition. In this type of composition, the motifs forming the composition are all oriented to the centre (Figures 8-9).

Figure 8. Iznik Plate $16^{\text {th }}$ Century

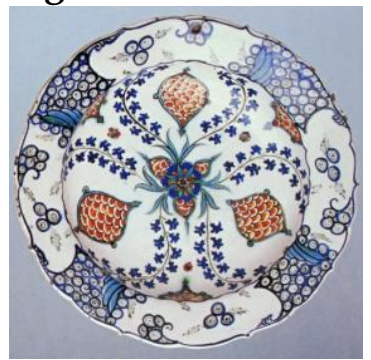

Source: Atasoy, \& Raby (1989), 303.

Figure 9. Iznik Plate $16^{\text {th }}$ Century

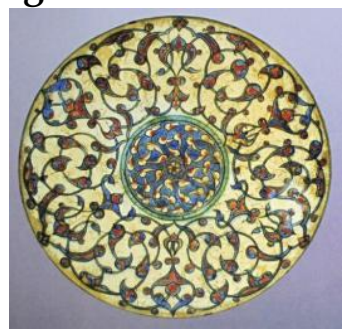

Source: Atasoy, \& Raby (1989), 216.

- Multicentric Compositions

This type of composition includes multiple arrangements. Each unit oriented around certain axes are again tied together in orientation to certain axes. In this arrangement each unit is linked to another in orientation to certain axes in order to form a whole (Figures 10-11). 
Figure 10. Iznik Plate $16^{\text {th }}$ Century

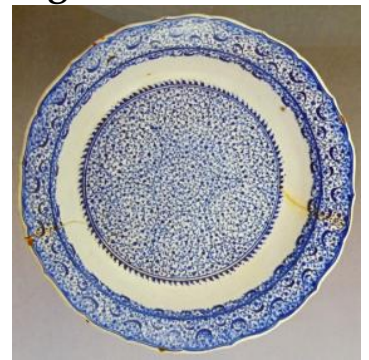

Source: Atasoy, \& Raby (1989), 168.

Figure 11. Iznik Plate $16^{\text {th }}$ Century

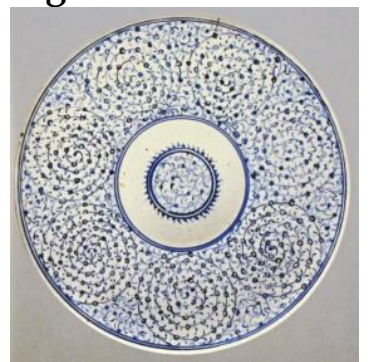

Source: Atasoy, \& Raby (1989), 173.

- Underglaze Decoration Technique

The pattern is drawn on parchment paper according to the decoration form (Figure 12). When drawing the design first a general composition is formed with the general outlines of the pattern, and then all lines of the motifs are filled in (Figures 13-14).

Figure 12. Preparing Composition for Plate on Parchment Paper

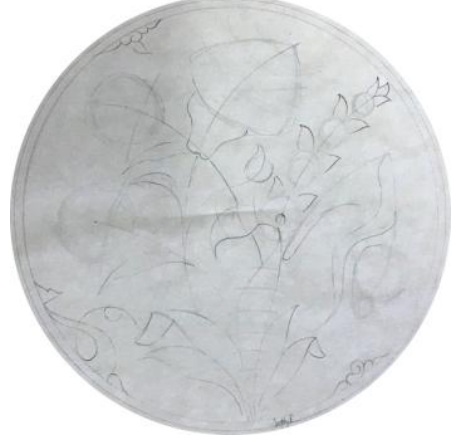

Source: Can Gökçe’s design, Personal Archive. 
Figure 13. Detailed Composition for Plate on Parchment Paper

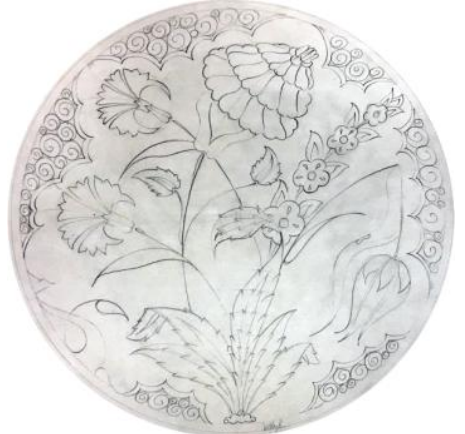

Source: Can Gökçe’s design, Personal Archive.

Figure 14. Detailing The Composition for Plate on Parchment Paper

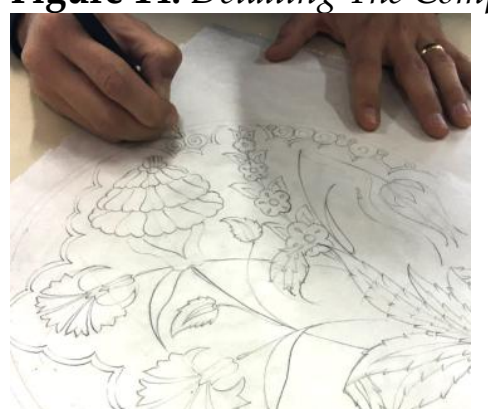

Source: Can Gökçe’s design, Personal Archive.

Figure 15. Detail of Pencil with Needle

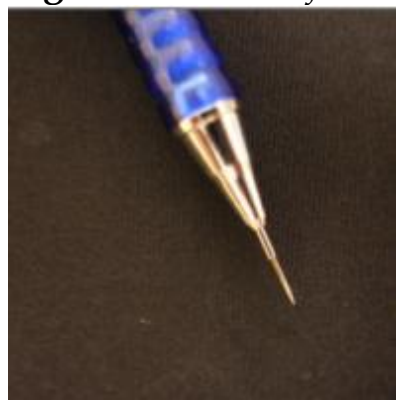

Source: Personal Archive.

Figure 16. Detail of Piercing Design on Parchment

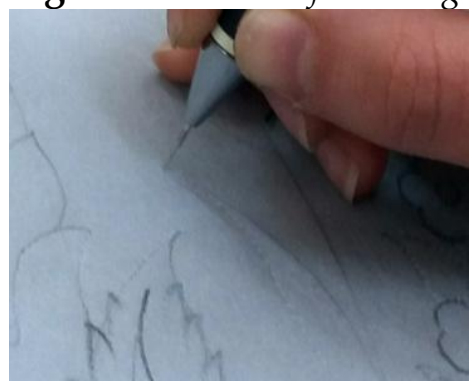

Source: Personal Archive. 
Figure 17. Sandpapered Biscuit Fired Form

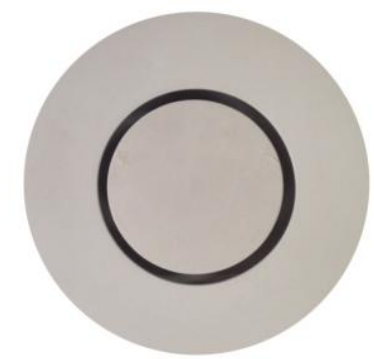

Source: Artworks of Mehmet Alp, Postgraduate Student at Usak University Institute of Social Sciences.

The drawn pattern is perforated by pins, generally by placing a bead pin in a mechanical pencil (Figures 15-16), and transferred to the form by using coal dust. The biscuit fired form must be firstly ground with fine sandpaper to obtain a smooth surface to ensure that the brush moves freely (Figure 17). The pattern transferred to the form by the coal dust can also be drawn in by a brush, but beginners may prefer to lightly draw over the pattern by a pencil. In ceramics the contour lines surrounding the motifs are drawn in black or blue, using a brush. This is called "tahrir." In the ceramics of Iznik essaying is performed with sable brushes (Figure 18). Generally number 3 sable brushes are used for this purpose, but number 2 and 4 brushes are also used for drawing outlines of motifs (Figures 19-20-21). Drawn outlines-contours include nuanced lining (thin-thick). Then motif painting stage begins.

Figure 18. Sable Brush

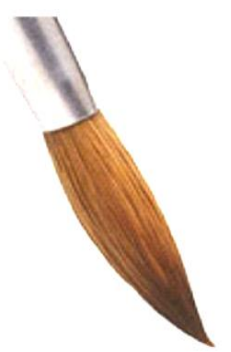

Source: Personal Archive.

Figures 19, 20, 21. Drawn Contours of Motifs

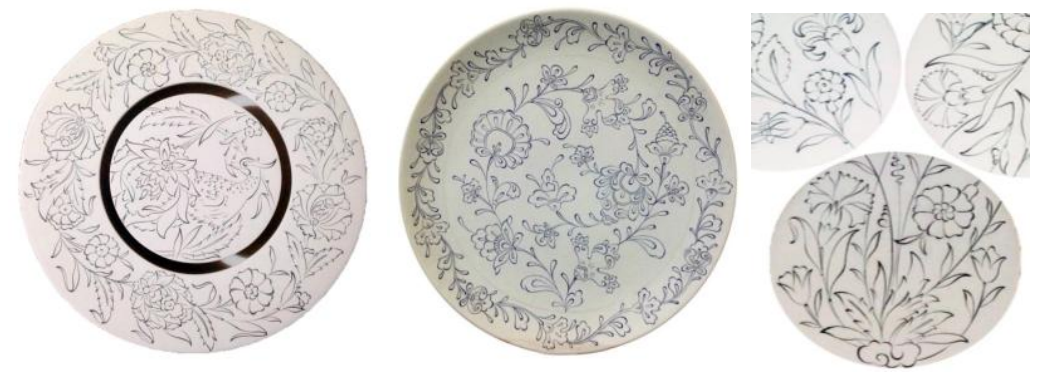

Source: Artworks of Mehmet Alp, Postgraduate Student at Usak University Institute of Social Sciences. 
Today many colours are used for ceramic decoration. However the classical colours include black, blue, turquoise, green and red. There are various characteristics to the use of these colours. Specially made horsehair brushes are used for painting (Figures 22-23-24).

Figure 22. Horsehair Brush

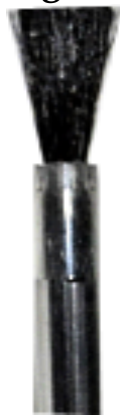

Source: Personal Archive.

Figure 23. Cut Horsehair Brush for Painting

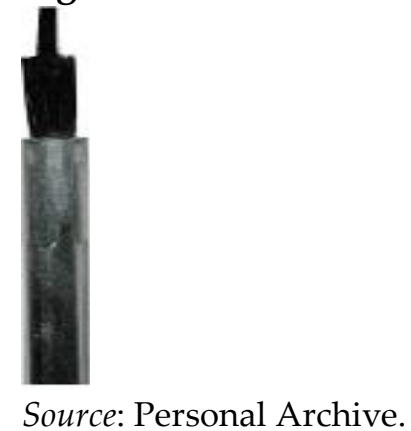

\section{Figure 24. Using Horsehair Brush}

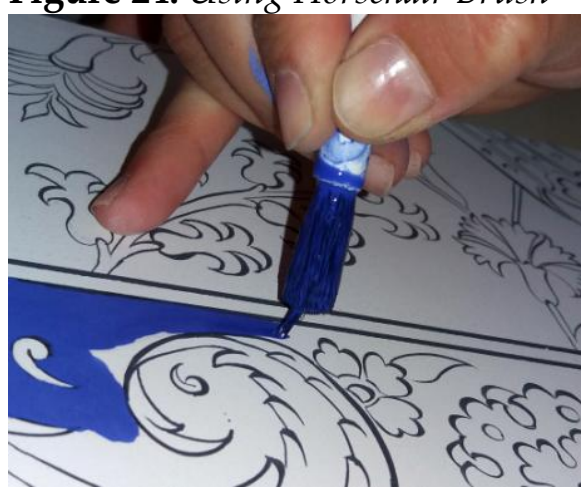

Source: Personal Archive.

First, colours are determined for the areas and motifs to be painted. The balance of motif placement in composition is also very important in the colouring phase. Colours should be distributed in a balanced fashion in order to maintain the integrity of the pattern. In addition, it is known that certain colours and application methods are preferred for certain motifs and backgrounds in ceramic patterns. 
The painting process starts with darker colours and proceeds in order towards lighter colours. Red colour is painted in multiple layers to provide embossment and to ensure the colour is clearly visible. During painting, care should be taken to avoid overlap between different colours. Colours other than red are not opaque. Especially motifs using blue and green colours include a shadowing (lighter-darker) application. Paint is diluted to lighten the colour. Starting painting with lighter shades allows for more control. After light colour application motif sections to be shadowed are repainted to darken the colour. Use of thick paint in the decoration process can cause loss of lustre on the glazing or occurrence of metallic effects (in copper containing paints). Therefore care should be taken especially when applying the shadowing effects. Turquoise paint must be applied in a thin and homogenous layer. Red paint should be applied in a thick and homogenous layer. Paint should be applied according to the characteristics and intended use of each paint. Otherwise undesired appearances can be encountered after firing.

In essayed patterns care should be taken to ensure that paints applied on determined motifs and backgrounds are applied in homogenous thickness and without corrugation according to the characteristics and intended use of each paint. The paint is constantly mixed and transferred to the paint brush. The paint is prepared by using a mixture of oxide pigments, glaze and mud. Since the mud sinks to the bottom paint should be mixed the from bottom to the top at each brush dip (Figures 25-38).

Figures 25, 26, 27. Decorated Ceramics (Berfore Glaze Firing)
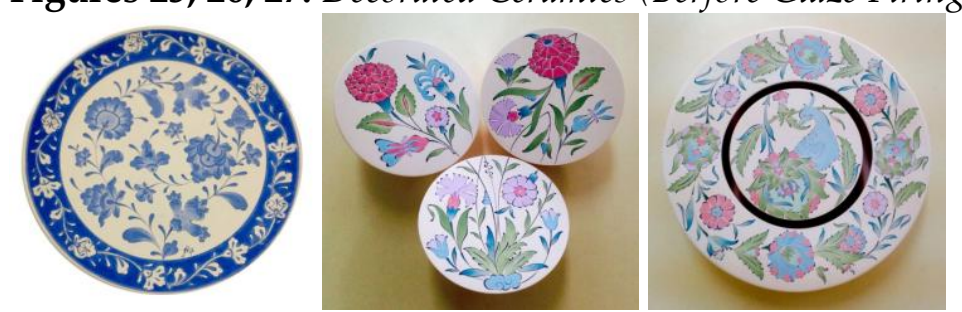

Source: Artworks of Mehmet Alp, Postgraduate Student at Usak University Institute of Social Sciences.

Figure 28, 29, 30. Decorated and Glazed Ceramics
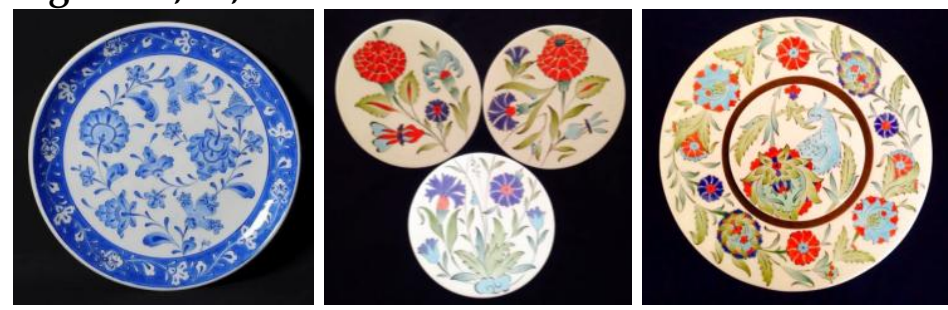

Source: Artworks of Mehmet Alp, Postgraduate Student at Usak University Institute of Social Sciences. 
Figures 31, 32. Can Gokçe's ${ }^{18}$ Artworks, Decorated with Classical Underglaze Technique (Ø: $82 \mathrm{~cm}$ )
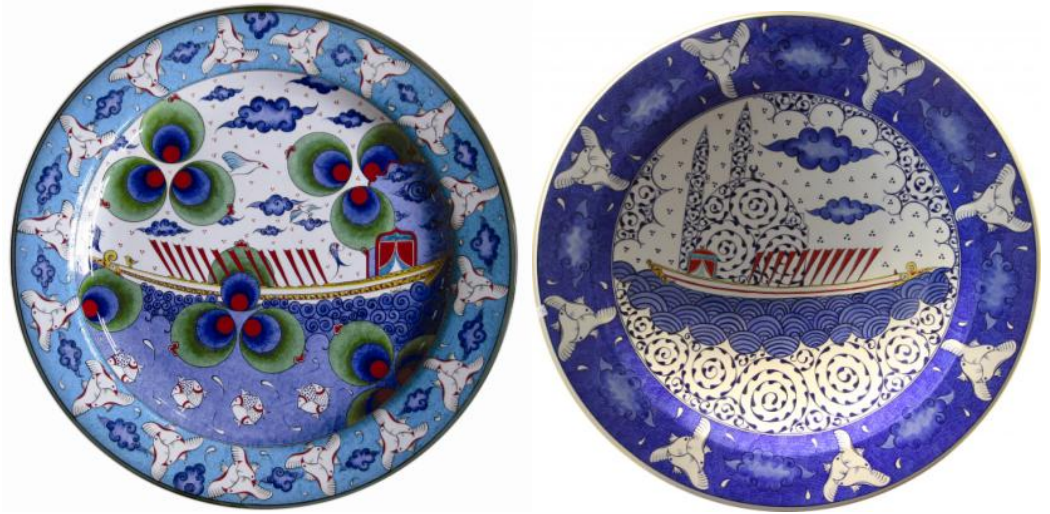

Source: Can Gökçe’s Artworks.

Figures 33, 34. Can Gokçe's Artworks, Decorated with Classical Underglaze Technique $(40 \times 60 \mathrm{~cm})$

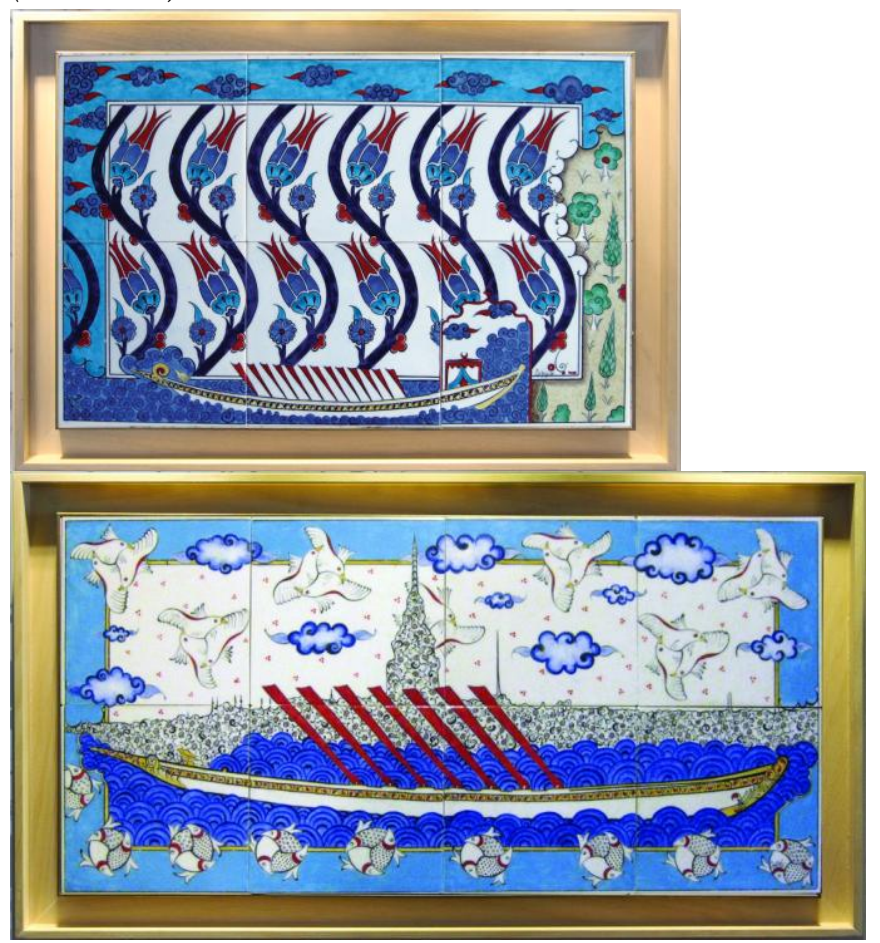

Source: Can Gökçe’s Artworks.

Today the ceramic glaze is adjusted according to the texture. Cracks and texture-glaze incompatibility can be seen especially due to some raw materials and substances used in Kütahya from time to time. The glaze used in these in a low degree transparent glaze with alkali-lead content. Glazing temperature varies between 930 and $1050{ }^{\circ} \mathrm{C}$.

18. Contemporary Artist Can Gökçe, Lecturer at Usak University, Architectural and Decorative Arts Program. 
Figures 35, 36. Ezgi Gökçe's ${ }^{19}$ Artworks, Decorated with Classical Motifs and Underglaze Technique
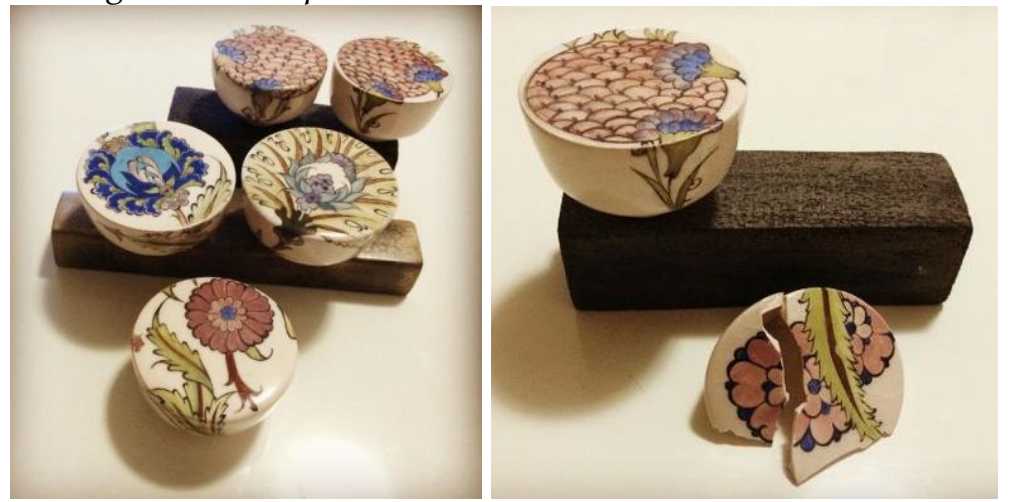

Source: Ezgi Gökçe’s Artworks.

Figures 37, 38. Ezgi Gökçe's Artworks, Decorated with Classical Motifs and Mixed Media
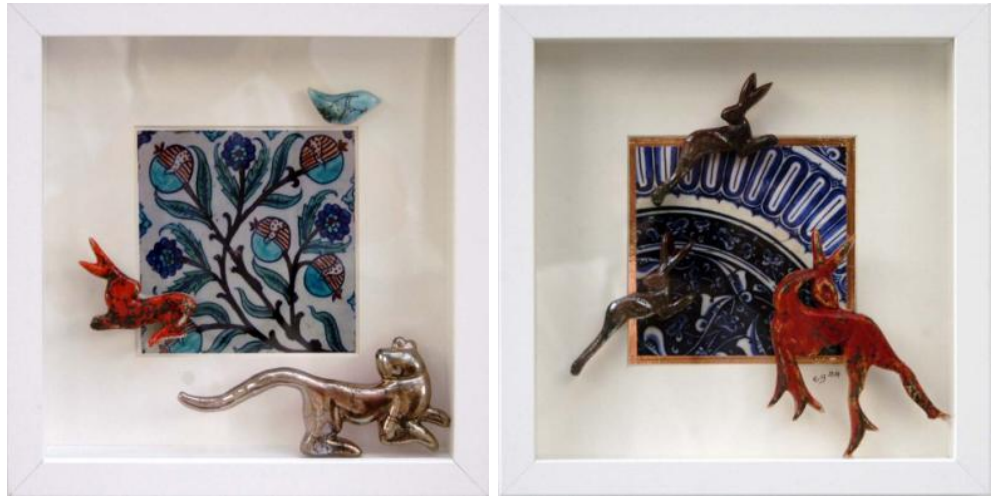

Source: Ezgi Gökçe’s Artworks.

\section{Conclusion}

The reason for the inability to produce ceramics of Iznik similar to the originals is the difficulty of finding written sources, or even the total lack of written records. The ceramics of Iznik, and even their copies, are still some of the most valuable ceramic pieces of many museums, private collections and auction houses. Traditional ceramic production is the field where expertise and experience are strict requirements. This heritage which holds such an important place in the world ceramic history must be conveyed to future generations by sharing the knowledge and continuing production.

19. Contemporary Artist Ezgi Gökçe, Lecturer at Usak University, Fine Arts Faculty, Department of Traditional Turkish Arts. 


\section{Bibliography}

Akar, Azade, \& Keskiner, Cahide. Türk Süsleme Sanatlarmda Desen ve Motif (Pattern and Motif in Turkish Decorative Arts). İstanbul: Sanat ve Kültür Yayınları, 1978.

Allan, James W. Abu'l-Qasim's Treatise on Ceramics. Iran, (1973), 11: 111-120.

Arlı, Belgin Demirsar, \& Altun, Ara. Anadolu Topră̆ının Hazinesi Çini Osmanlı Dönemi (Treasury of Anatolian Soil Tile Ottoman Period). İstanbul: Kale Grubu Kültür Yayınları, 2008.

Atasoy, Nurhan, \& Raby, Julian. Iznik Seramikleri (Iznik Ceramics). London: Alexandria Press, 1989.

Bakır, Sitare Turan. "Osmanlı Sanatında Bir Zirve Iznik Çini ve Seramikleri" (Copper, a Summit in Ottoman Art Iznik Tiles and Ceramics). In Anadolu'da Türk Devri Çini ve Seramik Sanatı (Turkish Revolutionary Tile and Ceramic Art in Anatolia). Edited by Gönül Öney, \& Zehra Çobanll. İstanbul: T.C. Kültür ve Turizm Bakanlığı Yayınları, 2007.

Bilgi, Hülya. Ateşin Oyunu: Sadberk Hanım Müzesi ve Ömer Koç Kolleksiyonlarından Iznik Çini ve Seramikleri (Fire Game: Iznik Tiles and Ceramics from Sadberk Hanım Museum and Ömer Koç Collections). İstanbul: Vehbi Koç Vakfı Sadberk Hanım Müzesi Yayınları, 2009.

Birol, İnci A., \& Çiçek, Derman. Türk Tezyini Sanatlarında Motifler (Motifs in Turkish Tezyin Sanatlar). İstanbul: Kubbealt Publications, 1995.

Carswell, John. Iznik Pottery. London: British Museum Press, 1998.

Denny, Walter B. "Painting on Ceramic," Studio Potter 31, no. 1 (December 2002). Art Source, EBSCOhost [Accessed: April 26, 2016].

_. Iznik: The Artistry of Ottoman Ceramics. London: Thames \& Hudson Press, 2005.

"Turkish Ceramics and Turkish Painting: The Role of the Paper Cartoon in Turkish Ceramic Production." In Essays in Islamic Art and Architecture in Honor of KatharinaOtto-Dorn. Edited by Abbas Daneshvari. Malibu: Undena Publications, 1981.

Fehervari, Géza. Ceramics of the Islamic Lands. London: I. B. Tauris, (2000), 305-310.

Keskiner, Cahide. Türk Süsleme Sanatlarında Stilize Çiçekler (Stylize Flowers in Turkish Decorating Arts). Ankara: Kültür Bakanlığı Yayınları, 2000.

Kürkman, Garo. Magic of Clay And Fire: A History of Kuitahya Pottery and Potters. Istanbul: Suna and Inan Kurac, Foundation, 2006.

Lane, Arthur. Later Islamic Pottery: Persia, Syria, Egypt, Turkey. London: Faber \& Faber, 1957.

Necipoğlu, Gürlu. "From International Timurid to Ottoman: A Change in Taste in Sixteenth Century Ceramic Tiles." Muqarnas 7 (1990): 136-170. 
Öney, Gönül, \& Çobanll, Zehra. Anadolu'da Türk Devri Çini ve Seramik Sanatı (Turkish Revolutionary Tile and Ceramic Art in Anatolia). İstanbul: T.C. Kültür ve Turizm Bakanlığı Yayınları, 2007.

Özkeçeci, İlhan. Türk Sanatı'nda Kompozisyon (Composition in Turkish Art). İstanbul: Yazıgen Publishing House, 2014.

Refik, Ahmet. "Iznik Çinileri - Hazinei Evrak Vesikalarına Nazaran" (Iznik Chinese - compared to Treasury Documents). Darülfünun Edebiyat Fakültesi Mecmuası 8, no. 4 (1932): 36- 55.

Şahin, Faruk. Türk Çini Sanatı Süslemeciliği (Turkish Tile Art Ornamentation). Anadolu: Anadolu University Publications, 1989.

Stanley, Tim. "Iznik Ceramics Between Asia and Europe, 1470s-1550s." Arts of Asia 41, no. 6 (2011): 123-132.

Watson, Oliver. Ceramics from Islamic Lands. New York: Thames \& Hudson, 2005. 
